\title{
Influence of Homogenization Annealing on Internal Damping Depending on the Vibration Amplitude Measured on Specimens AZ31 and AZ91
}

Zuzana Dresslerová, Peter Palček, Milan Uhríčik

University of Žilina, Faculty of Mechanical Engineering, Department of Material Engineering, Univerzitná 8215/1, 01026 Žilina, Slovakia. E-mail: zuzana.dresslerova@fstroj.uniza.sk, peter.palcek@fstroj.uniza.sk, milan.uhricik@fstroj.uniza.sk

Damping capacity of alloys is closely tied to the presence of defects including solute atoms, second phases and voids. The interaction between moving dislocations and point defects is one of the major internal damping mechanisms of magnesium alloys so the precipitates influence the damping capacity and contribute to damping properties. The article is focused on the analysis of the internal damping changes depending on the amplitude of the magnesium alloys AZ31 and AZ91 in as cast state and after homogenization annealing. In experimental measurements only resonance method was used. This method is based on continuous excitation of oscillations of the specimen and the entire apparatus vibrates at a frequency which is near to the resonance. Starting resonance frequency for all measurements was about $\mathrm{f}=20500 \mathrm{~Hz}$.

Keywords: Magnesium alloys, Internal damping, Vibration amplitude

\section{Acknowledgement}

This work has been supported by Scientific Grant Agency of Ministry of Education of Slovak Republic and Slovak Academy of Sciences $N^{\circ} 1 / 0683 / 15$ and by project APVV SK-CZ-2013-0076.

\section{References}

[1] SCHALLER, R., FANTOZZI, G., GREMAUD, G. (2001). Mechanical spectroscopy $Q^{-1} 2001$ with applications to materials science, pp. 683. Trans Tech Publications, Switzerland. ISBN 0-87849-876-1.

[2] SEUNGH, B. (2000). High damping Fe - Mn martensitic alloys for engineering applications. In: Nuclear Engineering and Design, Vol. 198, No. 3, pp. 241-252. ISSN 0029-5493.

[3] AVEDESIAN, M. M., BAKER, H. (1999). Magnesium and Magnesium Alloys, pp. 314. Materials Park OH: ASM International. ISBN 0871706571.

[4] FAN, G. D., ZHENG, M. Y., HU, X. S., WU, K., GAN, W. M., BROKMEIER, H. G. (2013). Internal friction and microplastic deformation behavior of pure magnesium processed by equal channel angular pressing. In: Materials Science \& Engineering A, Vol. 561, No. January 2013, pp. 100-108.

[5] ZHANG, Z., ZENG, X., DING, W. (2005). The influence of heat treatment on damping response of AZ91D magnesium alloy. In: Materials Science and Engineering, Vol. 392, No. 1 - 2, pp. 150-155. ISSN 0921-5093.

[6] GÖKEN J., SWIOSTEK J., LETZIG D, KAINER K. U. (2005). Damping Measurements of the Magnesium Wrought Alloys AZ31, AZ61 and AZ80 After Indirect and Hydrostatic Extrusion, In: Mat. Sci. Forum, Vol. 482, pp. 387-390.

[7] BLANTER, M. (2007). Internal Friction in Metallic Materials, pp. 539. Springer - Verlag: Berlin Heidelberg. ISBN 3-540-68757-2.

[8] HAO, G.L., HAN, F.S., WANG, Q.Z., WU, J. (2007). Internal friction peaks associated with the precipitation in AZ91 magnesium alloy. In: Physica B, Vol. 391, No. 1, pp. 186-192. ISSN 0921-4526.

[9] SOVIAROVÁ A., PALČEK P., BLAŽEK D., CHALUPOVÁ M. (2014). Analysis of Dependence of Internal Friction on temperature of Magnesium Alloy with Aluminium Addition. In: Period. Polytech. Transp. Eng., Vol. 42, No. 2, pp. 139-143. ISSN 1587-3811.

[10] UHRÍČIK, M., PALČEK, P., SOVIAROVÁ, A., SNOPIŃSKI, P. (2014). Change of Internal Friction on Aluminium Alloy with $10.1 \%$ Mg Dependence on the Temperature. In: Manufacturing Technology, Vol. 14, No. 3, pp. 467-470. ISSN 1213-2489.

[11] DRESSLEROVÁ, Z., PALČEK, P. (2014). Temperature Dependence of the Internal Friction Measured at Different Excitation Voltages. In: Manufacturing Technology, Vol. 14, No. 3, pp. 287-290. ISSN 1213-2489. 